\title{
EBSP 法を用いたマルテンサイト鋼のクリープ変形組織の観察
}

九州大学大学院総合理工学研究院 吉 田 冬 樹* 中 島 英 治* 阿 部 弘* 九州大学大学院生 寺田大将**
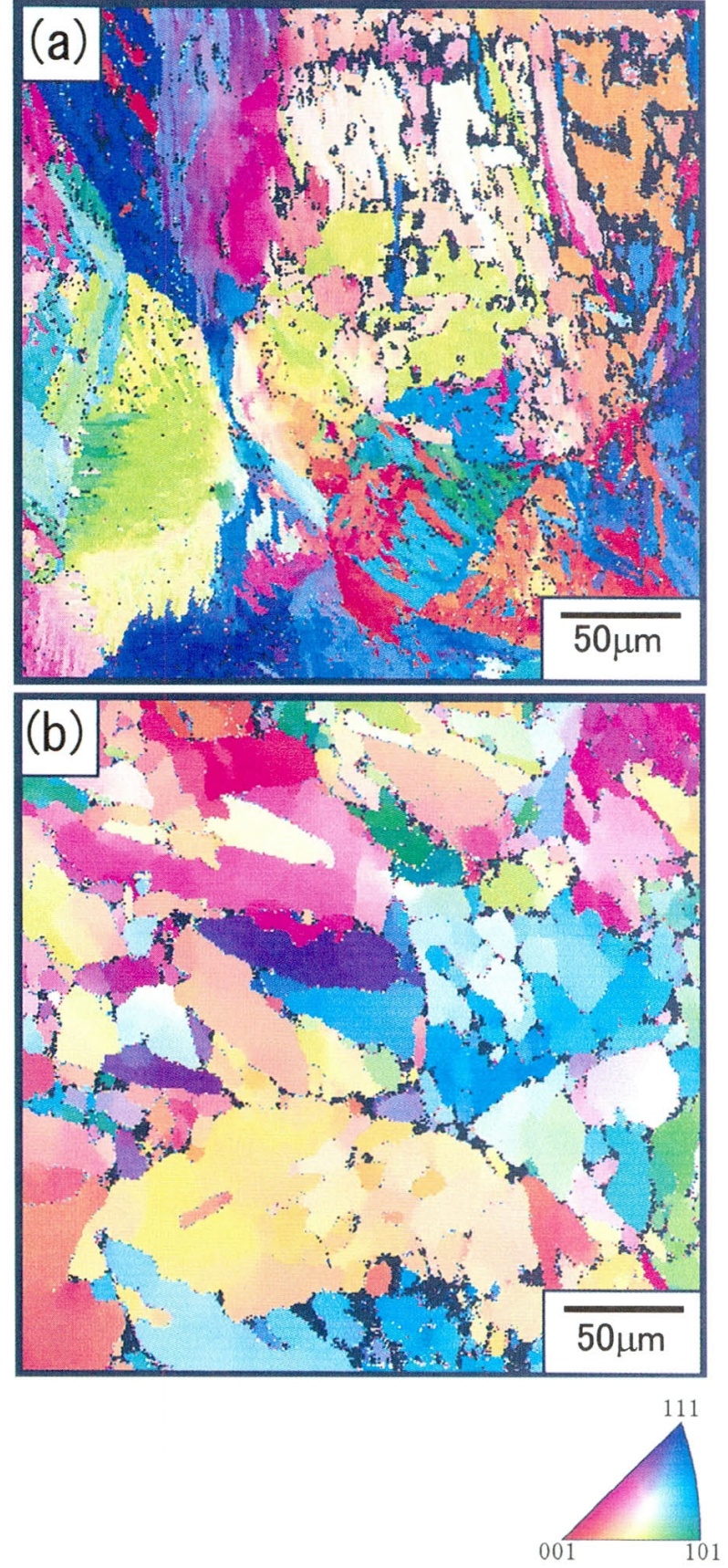

Fig. 1 9Cr-3W-3Co 鋼の未変形材 (a) と973 K-60 $\mathrm{MPa}$ クリープ破断材 (b)の結晶方位マップ.

焼戻しマルテンサイト組織を有する耐熱鋼は，使用 中に生じる組織変化によって高温強度が著しく損なわ れるため (1)，その効果的な抑制法の開発が望まれて いる.ところで，焼戻しマルテンサイト組織は変態に よって生じた高密度の転位と多くの粒界を有して纬

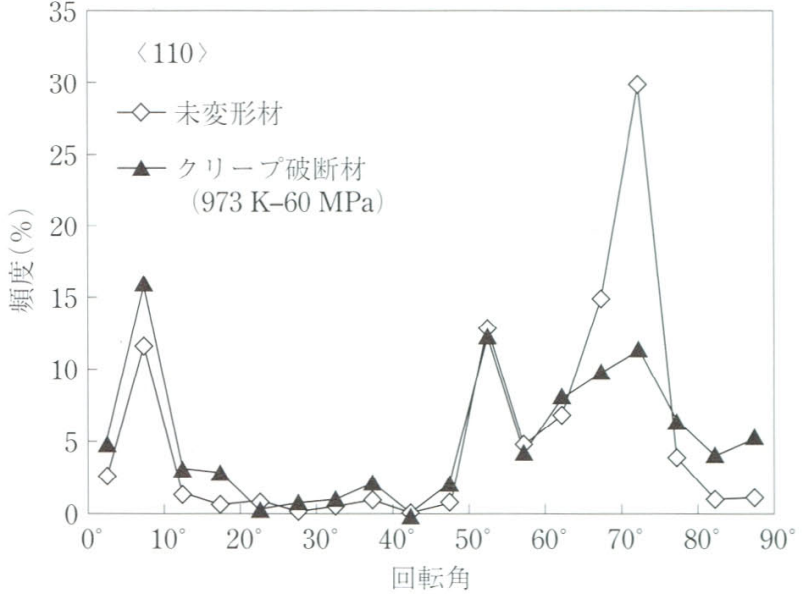

Fig. $2 〈 110 〉 を$ 共通回転軸とするブロック粒界の存在 頻度.

り，組織変化の抑制法を検討する際には，これらの各 要素のクリープ変形中の挙動を正確に把握して扎く必 要がある.Fig. 1 は，マルテンサイト組織を有する $9 \mathrm{Cr}-3 \mathrm{~W}-3 \mathrm{Co}$ 鋼の未変形材 (a) と $973 \mathrm{~K}-60 \mathrm{MPa}$ ク リープ破断材 (b) の SEM-EBSP 観察より得られた結 晶方位マップを比較したものである(2)。ここで, 図 中の色は標準ステレオ三角形に示した方位に対応して いる。また, 図中の黒い領域は, 明瞭な菊池線が得ら れなかった領域であり，高転位密度の領域であると考 えられる。図より未変形材では同系の色の部分がブロ ック粒と見なされ，それらが入り組んで沶り，また色 の変化も大きく，大きな方位変化が存在することが分 かる.これに対してクリープ破断材では，それぞれの 色で示した領域が等軸化し，方位分散も減少してい る。これらのことより，クリープ変形によって転位密 度の減少と結晶粒の形態変化を伴う組織変化が生じて いることが分かる。

Fig. 2 は SEM-EBSP 観察によって得られた結晶 方位より求めた，〈110〉を共通回転軸とするブロック 粒界の存在頻度を示す(2)。図より, 両試料とも回転 角が $10^{\circ}, 55^{\circ}$ 特よび $70^{\circ}$ 付近にピークが存在している. しかしながらその頻度はクリープ変形によって変化 乙, 回転角が $70^{\circ}$ 付近のブロック粒界が大きく減少 し， $10^{\circ}$ 付近のブロック粒界が上昇している。この結 果は，マルテンサイト組織の動的組織変化が，ある特 定のブロック粒界の熱的安定性に支配されている可能 性が高いことを示唆するものである。

\section{文献}

（1）九島秀和，木村一弘，阿部富士雄：鉄と鋼，85(1999), 841 .

（2）中島英治：耐熱鋼・耐熱合金の高強度化研究会最終報告書, 日本鉄鋼協会, (2000), 22-27.

(2000年 7 月 24 日受理)

EBSP Observation of Creep Deformed Microstructure of Martensitic Steel; Fuyuki Yoshida*, Hideharu Nakashima*, Hiroshi Abe*, Daisuke Terada**(*Faculty of Engineering Sciences, Kyushu University, Fukuoka, ${ }^{* *}$ Graduate Student, Kyushu University) Keywords: high temperature deformation, heat resistant steel, block boundary, electron back-scatter diffraction pattern Sample preparation: electropolishing SEM utilized: JSM-5310 $(25 \mathrm{kV})$ 